Marija Zurnić

Independent Researchers
УДК: 303.725::328.185(497.11)

Ориіинални научни рад

Примљен: 04. 06. 2014

\title{
RESEARCHING CORRUPTION SCANDALS IN SERBIA: NEW APPROACHES AND CHALLEGNES
}

This research is motivated by the striking gap between the ever increasing number of corruption scandals in Serbian politics and the lack of academic research on this topic. The article, firstly, presents an overview of the theoretical approaches, conceptualisations and definitions of scandals in scholarly literature. The second part of the study outlines preliminary findings based on 25 interviews conducted with Serbian state officials, academics and members of the NGO sector between 2012 and 2013. The findings indicate that two types of scandals can be differentiated in Serbian public discourse on corruption - afera and mafija. The author suggests that researchers of corruption scandals in Serbia can benefit from the wide variety of the existing theoretical approaches and the large number of case studies that Serbian media are offering.

Key words: corruption, political scandals, Serbia

\section{Introduction}

Scholarly studies on political scandals have become increasingly diverse and numerous. One of the reasons for this tendency is a large number of high-profile political scandals, which have occurred, since the mid-1970s, in many consolidated democracies such as the USA, UK, Germany and France. Meanwhile, opportunities for corruption increased with the rise of transitional processes in East European countries since the late 1980s. Many other developments contributed to the increasing number of political scandals in public discourse; these include, the development of modern technologies, enabling fast and accessible communication; the increasing influence of the media on politics and a change in understanding of the public and private spheres in political culture.

On several occasions, academics have suggested that "scandalogy" should be considered a field of research in its own right (Schutze, 1967: 11; Schmitz, 1981; King, 1986: 175; Markovits and Silverstein, 1988: 2). In the introduction to his study of scandals, published in the mid-1980s, Anthony King addressed this problem in the following way: "The rest of this essay constitutes a tentative, preliminary exploration of the field of scandalogy. It has to be tentative because theory in this new field is non- 
existent. It has to be preliminary because many data are not available [...] and also because many of the data that are available cannot be published [...]. What follows is a sketch-map that, with luck, will encourage other budding scandalogists to explore further" (King, 1986: 175).

Even though scandalogy is not considered a sub-discipline today - in a way that corruption or organised crime-related research is - the literature on political scandals has grown significantly since King's comment was published. Annex 1 in this article illustrates the increase in number of academic studies concerning political scandals, in all disciplines, over the past decades. In the 1960s, the literature included only one publication, while in the past decade it increased for over a thousand new publications.

\section{Political Scandal: Theoretical Approaches, Definitions and Typologies}

This literature review focuses on the studies concerning political scandals with the aim of bringing this theoretical and empirical research closer to the academic community dealing with Serbian politics and media studies. The review will aim to answer the following questions: What approaches have been taken in studying the impact of scandals on politics? To what extent do corruption scandals hamper or trigger institutional reform in the field of anti-corruption? The first question will be answered by exploring the ways in which the concept of scandal has been studied since the early publications in the 1970s until the latest research on scandals. Special attention will be paid to the academic debate concerning scandals and liberal democracies. The second question will be addressed by detailing the views on dys/functionality of scandals and arguments in these debates which position scandals as a spur to reform.

\section{Scandal and Liberal Democracy}

A major part of the research on political scandals begins with the assumption that political scandals can emerge only in democratic societies. Markovits and Silverstein, who explicitly state this view (1988: 8), define liberal democracy as a political system which has a clear separation between the private and the public realms and the rule of law, with fair elections and constitutional separation of secular and clerical authorities (Markovits and Silverstein, 1988: 4). In their view, scandals occur due to the misbalance of two opposing principles, inherent to liberal democracy, which are the need for power by the ruling elite and the need for curtailing that power by the citizens, in order to protect their autonomy from the state.

Today, studies of scandals continue to echo this idea by explaining that democratic values, norms and processes are a precondition for the existence of free media, 
active civil society, an independent judiciary and informed citizens interested in cherishing democratic values. For instance, Neckel points out that scandals emerge in systems where "power and control bodies must not coincide" (Neckel, 2005: 103). According to Neckel, no political scandals surface in dictatorships due to the lack of clear division of the branches of power, except when the ruling elite create and control scandals for their political interests (Neckel, 2005: 103).

Moreover, Esser and Hartung (2004: 1048) emphasise the importance of freedom of speech, independent media, and open and democratic societies as a precondition for the emergence of scandal. According to this view, no scandal could surface during the communist regime in the German Democratic Republic or the Soviet Union. In the same vein, Hondrich (2002: 48) suggests that the crimes committed under Stalin's regime surfaced later, during Khrushchev's government, when the restrictions to the freedom of speech became less harsh.

However, authors with the opposite view argue that political scandals do emerge in non-democratic societies and they have a significant impact on politics (Toepfl, 2011; Sabrow, 2004; Johnston, 1997; Klier et al., 1989). Martin Sabrow (2004: 24) goes further and argues that it is not the question of if, but in what way, scandals emerge in dictatorships. According to him, neither liberals nor communists, in modern history, could prevent political scandals (Sabrow, 2004: 22), which he confirms in his analyses of political scandals in the German Nazi state and the German Democratic Republic.

The opposing views on scandals in non-liberal democracies suggest that the authors understand and define the concept of scandal differently. Unlike Markovits and Silverstein, who view scandals as disrespect of due process, Sabrow refers to scandals as "the system adverse accidents" (Sabrow, 2004: 22) and understands them as an expression of modernity, which articulates social outrage against elites and the political establishment. Sabrow acknowledges the influence of the political elite on scandals in a non-democratic context, but he argues that free political scandals also emerge there (Sabrow, 2004: 25-6). Moreover, Sabrow explains that scandals have facilitated the establishment of dictatorships and their demise in the twentieth-century Europe and, as he noted, scandals were instrumental for the non-violent change of the communist rule in some East European countries (Sabrow, 2004: 15).

The latest research, which posits that scandals are possible in contexts other than full-fledged democracies, includes Florian Toepfl's study (2011) of political scandals in contemporary Russia. He explores the role of the internet, as a free communication media, in the emerging of political scandals from the grass-roots level, free from political influence. Moreover, Toepfl points out that academic research unduly neglects the "[...] 'grey area' of political regimes [...] that can neither be regarded as classic authoritarian nor as fully-fledged democratic" (Toepfl, 2011: 3). This grey area of 
political regimes has increased since the late 1980s, when most of the Eastern European countries began their transition to democracy. However, the political literature on scandals, as Toepfl points out, has not developed new theoretical and methodological tools in line with this change.

\section{Scandal and Institutional Change}

The theoretical framework, which was first applied to the analysis of scandal, was Durkheim's explanation of social integration, which argues that transgressions of norms are an intrinsic part of social life and that scandals are necessary for the maintenance of social order. In line with this assumption, Markovits and Silverstain explain that "the ritual of scandal and punishment provides social system with a means for self-legitimation and purification" (Markovits and Silverstain, 1988: 2). These authors add an important element to Durkheim's theory, which is, as they noted, "the central role of power in the construction of social reality, public morality and the conscience collective" (1988: 4, emphasis in the original). This novelty enabled political aspects of scandals to be analysed within a sociological approach.

From this perspective, political scandals were mainly interpreted as a consequence of political processes and a symptom of deeper structural problems of the system. The terms scandal and corruption were often used interchangeably (Doig, 1984; Noonan, 1987), as scandals were discussed as an illustration of political corruption rather than explored as political events per se. Scandals were generally considered negative political events, but useful in two ways. Firstly, scandal offered more insight into the hidden, complex patterns of political corruption. Moodie (1988: 243-4) pointed out that "[i]n the study of politics, as of the human body, a pathology is one route to understanding how things work."

Secondly, political scandals supposedly forced the authorities to undertake reforms, which further strengthened the liberal-democratic principles and made political systems resistant to such transgressions in the future. Markovits and Silverstein (1988: 9) argued that "[...] if political scandals did not exist, liberal democracies would have to invent them". Some researchers support this functionalist argument today by arguing that scandals can be understood as a sign of healthy liberal democracy (Rose-Ackerman, 1999; Blach-̌̌rsten, 2010).

As, in the 1990s, political scandals surfaced in liberal democracies more often than before, new perspectives on political scandals emerged in academic research. Firstly, the concepts of corruption and scandals became increasingly differentiated. Moreover, it was recognised that political scandals in liberal democracies can also be used strategically for political gain. The potential of scandals to influence social norms and value-systems was more in the focus of academic research. For instance, Johnston pointed out that "[...] the meaning of corruption, its application to particu- 
lar cases, and who gets to decide these matters can be hotly contested issues. [...] [I]t can politicize the concept and obscure its working boundaries, making it difficult to distinguish actual corruption from partisan scandal (Johnston, 1997: 63-4)." Moreover, scandals were increasingly understood as a reflection of the interests of the elites and underlying conflicts between them, rather than purely as an indicator of institutional defect.

Secondly, research in the late 1990s increasingly challenged the view that the emergence of scandals improves institutional setting and strengthens democratic values and norms. Later research further developed the dysfunctional theory of scandals. For instance, the outcomes of the major political scandal, Tangentopoli, which surfaced in Italy in the 1990s, gave reason to Vannucci and Della Porta (1999) to support this view. Vannucci (2009) argues that the dismantling of corrupt networks of high-ranking officials in Italian politics and judiciary had a short-term impact on curbing corrupt practices. As the police investigation focused only on the implicated actors, instead of on dismantling the social and institutional networks which enabled corrupt practices, the scandal had only a short-term anti-corruption impact. Moreover, the Tangentopoli case raised the "scandalisation threshold" and eventually decreased public interest in the problem of corruption (Vannucci, 2009: 240).

Della Porta and Vannucci further argue that economic incentives and cultural values are path dependent and "high levels of corruption in the past produce in the present increasing returns [...] by providing organisational shields and mechanisms of protection against external intrusion by the authorities and internal friction among corrupt actors" (Della Porta and Vannucci, 2012: 1). These findings strongly oppose the functionalist assumption and suggest that corruption scandals may strengthen the existing patterns of corrupt exchanges, as they eliminate weak links from the networks.

\section{Scandal as Mediated Event}

In the late 1990s, scandalogy was still considered an underdeveloped field of research and Rodney Tiffen described it as a "theoretically messy area, with an absence of general propositions or a tradition of scholarly achievements on which to build cumulative research" (Tiffen, 1999: 11). A significant change was made by Tiffen's study Scandal, Media, Politics and Corruption in Contemporary Australia (1999) and by John Thompson's book Political Scandal: power and visibility in the media age (2000). The authors introduced major theoretical and analytical innovations by stressing the close relationship, in all modern societies, between the political sphere and the sphere of the media. According to this view, political scandals cannot be analysed without looking at the media reporting about the event. 
Thompson's approach, based on his previously developed social theory of the media (Thompson, 1995), explains that the fast technological development, which started with the invention of the radio, telegraph, telephone and television, enabled a simultaneous and dislocated reporting about the misconduct of politicians. Thompson defines scandals as mediated events (2000: 39) and emphasises their impact on the public. Mediated scandals, according to Thompson, have the power to involve the audience in discussions about the scandalous events, which are not directly related to their everyday life. Moreover, as Thompson points out, political scandals became more present in the public discourse due to radical changes in the political and journalistic culture - it has become widely accepted, Thompson argues, that the private life of political leaders, such as their moral views and lifestyle, are issues of public interest.

While Thompson stresses the shift of the dividing line between the public and private, Tiffen explores the increasing influence of the media on the way political scandals are presented in the media. In his analysis of sixty political scandals in Australia, Tiffen explains the communication strategies, which increased the impact of the media on political processes. For example, framing and agenda-setting can direct public attention to certain aspects of the story rather than to others. Tiffen also points out that scandals are dynamic rather than static events: "They are not debates about an incident frozen in time, but developing dramas where it is the weight of contemporary opinion and influence that will determine the outcome (Tiffen, 1999: 157)". This suggests that a thorough analysis of a scandal should take into account the story in its entirety, including the scandal's second-order themes, different interpretations and versions of the event which emerged in public discourse after the major event.

In the earlier research, scandals were understood in line with the legal definition of corruption. According to Thompson and Tiffen, instead, it is the public-opinion based definition of corruption that lies in the core of scandals. ${ }^{1}$ Moreover, they understand scandals as an intrinsic part of political life and not as an occasional unexpected outcome of political processes. Scandals are viewed as political events with a specific nature and dynamic, and it is not necessary to analyse them in relation to corrupt practice. In the same vein, Adut points out: "scandals have life independent of misconduct" (Adut, 2008: 2).

Lastly, the tendency in researching scandals was to focus on their impact on the level of trust and on the reputation of actors involved in the transgression. It is impor-

\footnotetext{
${ }^{1}$ Perception-based definitions name corruption as white if both citizens and officials perceive it as acceptable or functional; as black, if both citizens and officials agree that certain corrupt actions are bad and dysfunctional; or as grey if the public and officials disagree on dis/functionality of the corrupt act (Heidenheimer 1970).
} 
tant to mention that the culturalist explanation of scandals, which underlies these approaches, assumes that scandals are caused by the change of values and norms. At the same time, scandals are catalysts for value change (Newell, 2006:7). The culturalist understanding of political scandal is summarised in the following definition: "Scandals rest on public values, help define them and do not have fixed contents" (Garrard, 2006: 17).

\section{Scandal and Public Opinion}

Besides cultural theory, the research on scandals includes an increasing number of quantitative studies which are, within institutional theory, concerned with the impact of scandals on various aspects of political life. The research on the electoral consequences of political scandals includes a wide range of studies (Costas-Perez et al., 2012; Pattie and Johnston, 2012; Vivyan et al., 2012; Vannucci, 2009; Jimenez and Cainzos, 2006; Cowley, 2002; McAllister, 2000). The impact of negative campaigning on voter mobilization has been widely explored, especially in the US context, where negative advertising is often present in electoral campaigns. Empirical studies reveal that exposure to negative advertising is associated with an increased level of turnout (Djupe and Peterson, 2002; Finkel, 1993; Geer and Lau, 2006; Jackson and Carsey, 2007; Jackson and Sides, 2006). This, however, does not contradict the findings that negative advertising lowers the level of trust in government (Craig and Kane, 2000; Globetti and Hetherington, 2000) and increases the overall negative perception of politics (Allen and Burrell, 2002; Lau et al., 2007).

Other widely-explored topics are the impact of scandals on public perceptions of illegality (Dafydd, 2005; Olukoyun, 2004; Pujas, 1998), the impact of scandals on support for institutions and democracy in general (Morris and Clawson, 2007; Maier, 2002), on public trust in government (Memoli, 2011; Damico et al., 2000), on the popularity of individual politicians and government leaders (Martorano and Ulbig, 2008; Boas, 2005; Bowler and Karp, 2004) and so forth.

Early research on the Watergate Scandal (Dunham and Mauss, 1976; Sniderman et al., 1975) supported the functional theory, as their findings suggest that particular political scandal improved public opinion and increased levels of trust in the government. More recently, Maier's (2002) analysis of the impact of political scandals on political disaffection in Germany suggests that the television reporting of political scandals had a positive impact on the support and evaluation of the political elite in general, and on satisfaction with democracy. Other research supporting the functionalist theory of political scandal includes: Kepplinger (2001), Kepplinger and Ehmig (2004), Sabato et al. (2001). The opposing argument is put forward in studies, which focus on political support after major scandals in Germany (Bytzek, 2007), in Italy 
(Della Porta, 2000; Memoli, 2011), in the UK (Bowler and Karp, 2004), in Nigeria (Olukoyun, 2004) and so forth.

In his recent article, Maier (2011) compared and tested the two theories of political scandals - the functional and the dysfunctional one. The focus was on the political scandals in Germany and their impact on public trust in political parties, institutions and the system. The results suggest that the trust in institutions and the satisfaction with democracy were not affected by the scandals, while the trust in politicians individually and in political parties decreased. As Maier suggests (2011), this trend is encouraging as it indicates the lack of the 'spill-over effect', that is that the voters evaluate political elite differently and separately from institutions and the system. However, the author points out that this gap between specific and diffuse support can be interpreted as a symptom of a political crisis: "while citizens prefer democracies over dictatorships, they dislike the representatives of democracy" (Maier, 2011: 293).

\section{Scandal and Communication}

The research on scandal, conducted in the field of media studies, understands scandal as a communication process (Entman, 2012; Schudson, 2004; Tumber, 2004; Tumber and Waisbord, 2004). The structural causes of scandals are not included in the focus of this approach; neither are the value systems in which they emerge, or the content of the media reporting exclusively on such topics. The focus is on scandals as "dramatization, storytelling and attractions" (Ekstrom and Johansson, 2008: 61), which are constructed in socio-cultural contexts with specific "social organisation of moral and political accountability" (Tileaga, 2012: 208). Instead of asking why actors involved in scandals react in a certain way, the researchers explore the reactions of actors in different contexts and societies. Tileaga summarises these research interests in the following way: "The focus is on the locally generated interpretive procedures, locally contingent moral reasoning that serves some purpose: setting the scene of the 'morality play', proffering an accusation or defence, painting an image of the person, explaining behaviour and context, discounting responsibility, and so on" (Tileaga, 2012: 208).

Scandals are understood from this perspective as "socially selected - or constructed - communication patterns" (Esser and Hartung, 2004: 1065). The communication approach to scandals explores the relationship between actors, misconduct and the audience, as these elements are considered to be connected in the public discourse by use of moral language (Tileaga, 2012: 204). For example, researchers focus on the agenda-setting media strategy (Williams and Delli Carpini, 2000; Brezina and Phipps, 2010; Entman, 2012), and on the media gate-keeping and other styles in reporting about scandals. Some authors explore the aims and outcomes of these communication strategies, which include political image restoration, de-legitimation and 
so forth (Blaney and Benoit, 2001). Lastly, the research interests in this area include the interaction between political scandals and other discourses and concept-formation processes (Kepplinger et al,. 2012; Ailon, 2012; Renwick et al., 2011; Kepplinger, 2001).

\section{Literature on Corruption Scandals in Serbia}

The available information indicates that Serbian academic literature includes one publication on the topic of political scandals. It is a chapter in Slobodan Antonić's book Elites, Citizens, Weak States: Serbia since 2000 (2006), which is dedicated to the controversial privatisation of the Serbian steel factory Sartid. The author focuses on the role of domestic and foreign political elites in this process of privatisation and argues that local politicians used a wide range of communication strategies in order to gain support for their decisions and to protect their private and party interests. The study offers insightful information, as the author explores the frequency and framing of the local media news concerning the case. The publication is highly relevant, not only for being the only one in this field, but because of its insightful analysis of the media news in relation the elite's reaction to the scandal. Since the privatisation of Sartid remains one of the controversial topics in public discourse, Antonić's study from 2006 represents the first step in this area of study, still lacking follow-up or critical approach in form of academic work.

It is important to mention that another academic work was consulted in this research. It is an unpublished work, which was authored in 2012 by Tanja Svilanović, a postgraduate researcher at the University of Belgrade. Svilanović analysed a scandal in Serbian politics, relating to the privatisation of the company, C-Market. She explored the transgressions and misconduct of the domestic political elite during the scandal, in relation to the process of social stratification in Serbia. Svilanović's research offers insightful information concerning the case, which was gathered through content analysis of local media news and interviews with actors involved in the privatisation scandal. The dissertation is a promising sign that the topic of political scandals might gain more attention in the Serbian academic community in the near future.

The latest and one of the few non-academic publications on political scandals in Serbia is a journalistic investigation On the Deeds of Weak Institutions (2013), which was recently published by Miša Brkić. The book gives an overview of seven political scandals which emerged in the process of privatisation, public procurement and military affairs between the year 2000 and 2008. The book offers interesting and informative quotations from politicians' speeches. However, the text fails to offer a theoretical framework for discussion and the criteria used for the selection of the case studies. 
The following figure shows the conceptualisations of political scandal, which are identified in the reviewed literature - institutionalist, culturalist and communication approach - and summarises the causes of scandals and their impact within each theory.

Figure 1. Approaches to political scandal in academic literature.

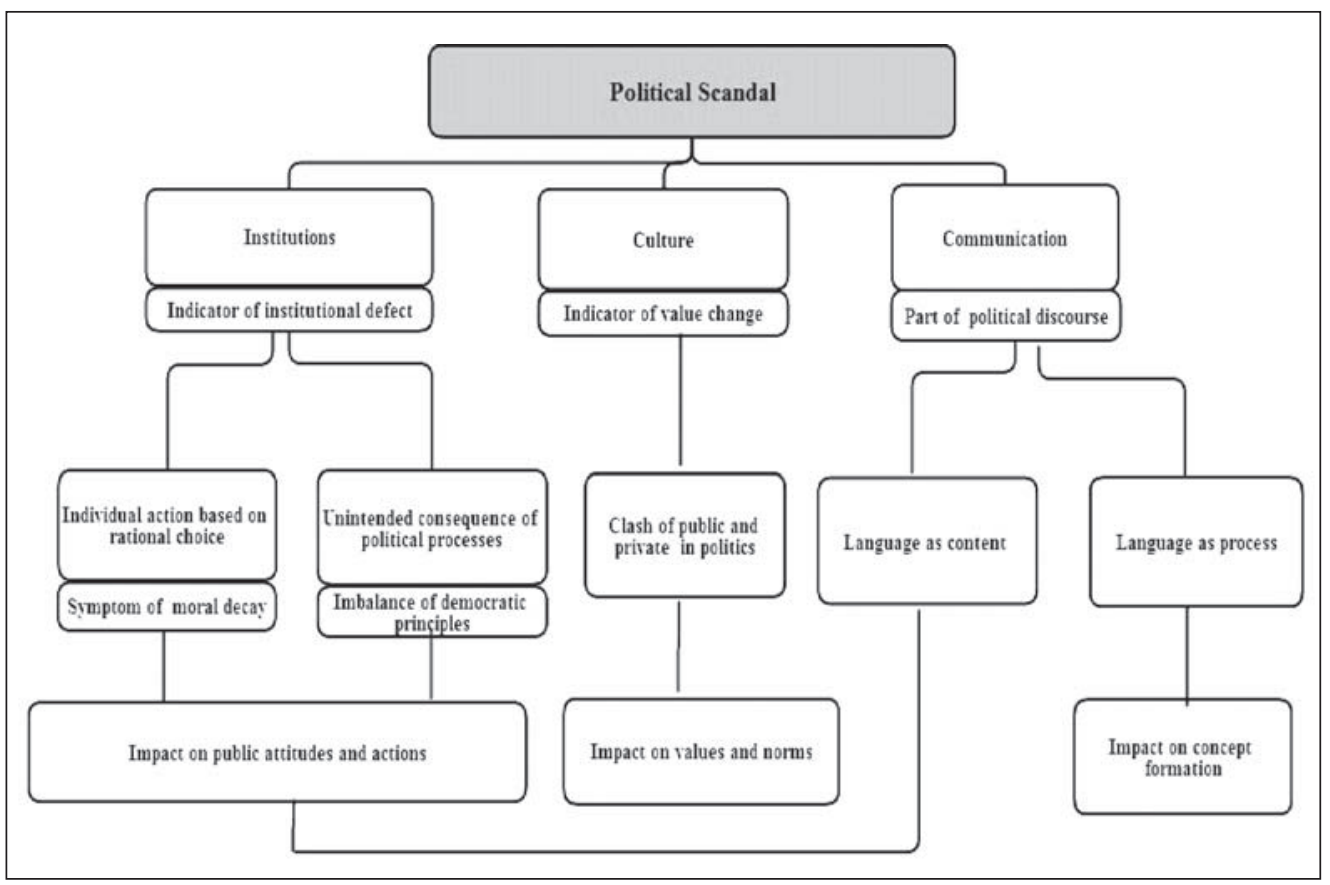

\section{Operational Definitions and Classifications of Political Scandals}

Researchers exploring scandals tend to apply two approaches when selecting their case studies - they follow either an objectivist or constructivist approach to operational definition of scandals (Entman, 2012: 4; Adut, 2008; Nyhan, 2009; Nyhan and Tofias, 2008). The objectivists assume that the relevance of political misconduct is proportional to the amount of media news about it. Therefore, the main criterion for considering a story scandalous is the extent of the media coverage, while the type of transgression and the accuracy of the story are in the background. Therefore, the objectivist definition of scandal can be summarised as "the most reported event in the media". Well-known examples of this type of operational definition include Larry Sabato's study on scandals, Feeding Frenzy (1991). 
The drawback of this approach originates in the assumption that the nature, frequency and type of political misconduct are adequately and proportionally represented in the media news. Recent studies confirm, however, that misconduct which involves high-ranking state officials and has highly negative impact on the public may sometimes pass unnoticed in public discourse. Robert Entman (2012), points out that the media attention to certain transgressions, even though this attention might "seem arbitrary and capricious journalism" (Entman, 2012: 1), sometimes has an underlying logic. In his study of political scandals in the US, Entman argues that governmental bodies and political parties have more influence on a misconduct becoming a scandal, than the media and investigative journalists. Therefore, he distinguishes between scandals and potential scandals. They involve similar transgressions, but do not get equal media attention.

For constructivists, the decisive element in classifying a story as a scandal is public reaction to the reported misconduct (Adut, 2008; Nyhan, 2009), or as Entman pointed out: "No public indignation, no scandal" (Entman, 2012: 5). Esser and Hartung (2004) explain the constructivist approach to scandal in more detail: "We can define scandal as the intense public communication about a real or imagined defect that is by consensus condemned, and that meets universal indignation or outrage. The two unspecific elements in this definition, the intensity of communication and the degree of consensus about the condemnation of the defect, must be made more concrete for an operational definition, but this is of no concern here. It should also be stressed that this definition of scandal does not assume that a defect actually exists" (Esser and Hartung, 2004: 1041).

As for typology of scandals, the first one was introduced by Thompson (2000). He classified scandals according to the type of misconduct as power-related, money-related and sex-related scandals. This classification has been expanded over time and has been complemented with new findings (Basinger and Rottinghaus, 2012; Van Dalen and Skovsgaard, 2011; Garrard, 2006; Doig, 2004; Kerby and Chiari, 2002). The latest contribution includes Basinger's and Rottinghaus' (2012) classification of scandals according to the level of government where the transgression took place. For example, Basinger and Rottinghaus focused their research on presidential scandals. The shortcoming of this approach is, as the authors admit, the difficulty of deciding how many people are considered to be related to the President's cabinet, who exactly these actors are and in what way they are considered to be related. In the same study, Basinger and Rottinghaus make another contribution to Thompson's classification by introducing the category of international scandal, which involves a violation of national laws due to involvement in the politics of another state, such as in the case of the Nicaraguan Contras during Reagan administration. 
As for the type of misconduct, Basinger and Rottinghaus include private and sex-related scandals in presidential scandal transgressions, but exclude gossip, rumours and dubious information about the private conduct of Presidents. Moreover, unwise and unpopular actions of the political elites in power, such as the mismanaging of wars, crises, policies and personnel do not necessarily turn into scandals (Basinger and Rottinghaus, 2012: 217). Adut is of the same opinion and he argues that "[c]ontroversial policies [...] don't constitute scandals. Nor does low performance in office [...] A significant political scandal will typically involve identifiable transgressions with certain offenders - not simply abstract criticisms - and require some kind of institutional reaction" (Adut, 2008: 74-75).

Another change to the classification of scandals was introduced by Kerby and Chiari (2002), who defined a specific type of policy scandal, which involves transgressions and misconduct which was revealed in the media only after a political actor left their position. Kerby and Chiari focus on the reaction of political actors to the scandal, which can damage their reputation even though they are not involved in it. His findings suggest that politicians tend to avoid the loss of reputation and symbolic capital in a twofold way: at the individual level, politicians shift responsibility in public debates on the scandal back to their predecessor; at the institutional level, the actors involved in policy scandals can take action in order to show their commitment to an official investigation of a case. They tend to establish commissions and task groups, especially if the scandal emerged in a contentious issue area such as health care, defence or the agricultural sector. According to Kerby and Chiari, such initiatives are only strategies for reducing political cost and avoiding criticism, as they "effectively insulate, and later kill, the scandal" (Kerby and Chiari, 2002: 412).

In sum, the way in which scandals are operationally defined and classified has direct implications on the findings. As mentioned earlier, Entman (2012) points out that defining scandals according to the number of media news reports, is not fully reliable. His findings suggest that the media in the US tend to have a selective approach to publishing scandalous transgressions. Moreover, Basinger's and Rottinghaus' study suggests that findings concerning presidential scandals in the US can be significantly different from those at other levels of government. Therefore, presidential scandals can be misleading, according to Basinger and Rottinghaus, if we want to obtain a general idea about transgressions and misconduct in the US politics. Therefore, in line with Basinger's and Rottinghaus' advice, it is necessary that "we should hesitate to criticize the ordinary based on our observation of the extraordinary" (Basinger and Rottinghaus, 2012: 236). 


\section{Empirical Research on Corruption Scandals in Serbia: Preliminary Findings}

This research does not aim at offering a comprehensive typology of corruption scandals in Serbia. Instead, its goal is to contribute to a better understanding of the concept of a corruption scandal in the Serbian context. The following section will outline research findings based on 25 semi-structured interviews conducted with six Serbian state officials, one politician, five academics, seven journalists, and eight members of the NGO sector. The fieldwork was conducted in Serbia and it consisted of three phases. Firstly, a week in February 2012 was dedicated to identifying available interviewees. Then, from 22 May to 22 August 2012, I conducted a large number of interviews with the selected and available interviewees. The third part, in May 2013, helped me confirm and complement the information, which had been gathered during the previous phases of the fieldwork.

It is important to mention that the main challenge during the field research was the reluctance of some members of the elites to participate in my research. This can be partially explained by the fact that the political situation was tense after the general elections, held in early May 2012. Even though the topic of corruption scandals, and the problem of corruption more generally, is a live issue and it is widely discussed in public discourse, significantly less interest was shown by some actors, especially politicians, state officials and businessmen, in stating their opinion. Moreover, certain scandals were at that time and still are, under investigation, or are related to other controversial cases, which are still being investigated. Therefore, majority of civil servants contacted for this research were reluctant to discuss the cases.

As research findings suggest, two terms are used in the public discourse about corruption for the concept of corruption scandal. These are afera and mafija. Afera (from fr. l'affaire: business, matter) is a story about an incidence of corruption in the sphere of business and politics. The majority of the interviewees defined afera as the discovery of illegal or unfair spending of public money, where high-ranking state officials and politicians are alleged to be involved but are never scrutinised or prosecuted; once the case is revealed to the public, the story about it is followed by the media for a while, and then abandoned until it is opened again. The majority of the interviewees perceived the launching of aferas and their later re-openings as planned events and aimed at goals other than fighting corruption. One of the interviewed journalists, who insisted on anonymity, explained:

"When I hear the word afera, the fist thing that comes to my mind is something that is used in political infightings. If you ask me whether behind it [afera] there is a genuine intention to fight corruption.... I'd say that there is now, more than before, but at the beginning there was none." 
As mentioned previously, the afera cases are rarely investigated by the police and even more rarely are alleged perpetrators prosecuted by the courts. This raises mistrust of the country's judicial system and doubts regarding the political will of the elites to combat this kind of corruption. What is more, these events add to the perception that all politicians are corrupt because they seemingly have no interest in pushing for investigations or prosecutions - which might suggest, according to some interviewees, that most of the politicians are either directly involved in the scandal or they are protecting others from being exposed.

According to the interviewees, the fact that afera does not have an epilogue in a court of law, and its key actors are not punished, makes the reopening of the case possible. Reopening means that the scandal is brought back to the public discourse, its investigation is presented as one of the priorities of the political elite, and is intensively covered by the media. The reopening usually happens during electoral campaigns. Each time the public debates the case, hopes are raised that those involved in the scandal will be adequately punished. For instance, the afera concerning the privatisation of the metallurgy factory Sartid was reopened more than four times in ten years and still lacks a final court decision on its legality.

As for the origin of the afera, the interviewed journalists argued that information which is crucial to the launching of an afera usually comes from sources in the police, the public prosecutor's office, or from ministers who leak the information to 'their favourite journalist':

"I'm deeply convinced that they [aferas] are launched by politicians and by the Prosecutor's office that works at politicians' instructions, even though it should be independent. They are launched directly from the politicians' cabinets, for example by the minister of interior or justice. They leak the information to certain journalists who work for them or they offer the information to certain media outlets in order to promote their own work or the work of some politicians or to denigrate their opponents... then, other media share that story by simply copy-pasting the information."

This explanation is in line with what most interviewed journalists argued: apart from their own work, there is no independent investigative journalism in Serbia. Some journalists argued that political and media elites work together in managing and launching scandals on a daily basis:

"The media in Serbia are very susceptible to political influence. Journalists are lazy to do investigative work, they simply forward the information just like a boiler circulates water. The situation in Serbia [concerning the media] is so transparent that I know right away where some information could have come from. We know who leaked the information to Blic, I mean... we know which source each journalist uses and who could have given them that particular information." 
This interviewee also pointed out that the opposition is less likely to be the group that launches scandals, because it has no 'access' to the media. This view is supportive of the argument concerning the strong media capture by the parties in power, which was put forward by the State Anti-Corruption in their Report on Pressure and Control over the Media in Serbia (2011). An interesting observation of an interviewed journalist is that the opposition instead uses parliamentary debates to make references to suspicious developments in business and politics. However, these references do not develop into afera, even though the parliamentary debates are open to public and journalists:

"I've been following the parliamentary debates for a long time. I noticed that very serious allegations can be made there, but those allegations never get investigated nor by journalists or by the Prosecutor's office. Sometimes, during one debate only, they mention about 26 criminal offences against each other and then they argue who's right. Transcripts from those debates are available. The parliamentary sessions are open to public, so journalist can come too, but for some reason those cases never develop into a scandal."

The interviewees offered different interpretations of the impact of afera on political life. For instance, it was argued that sensationalist media tend to increase their popularity by using populist stories and uncritical reporting. Also, some interviewees stated that afera influences electoral results, as politicians in Serbia tend to use two strategies when making promises of economic development in the country. One is that the fight against organised crime and corruption will bring about economic improvements. The other strategy uses the claim that accession to the EU will supposedly bring about political and economic stability. Since the former is easier to demonstrate and can effectively motivate voters, launching an afera is a suitable tool for confirming anti-corruption commitment in election campaigns.

Lastly, afera is understood as a means of political communication between the ruling coalition partners. According to an interviewee who shared this view, an afera is an instrument for informal political communication:

“I tend to think that we don't even have scandals. That's just a regular way of communication in the political sphere [in Serbia]. The point is that occasionally small part of it [information] leaks into the public sphere while major part doesn't. Scandals are part of everyday life here, because there are no rules. It's not like in the West where scandals are some sort of exception or aberration which disturbs the regular course of life or business."

Coalition parties collect potentially damaging information on their political partners - but do not publish this information or ask for investigations based on their findings - in order to have more leverage in negotiations with other coalition partners. 
Moreover, due to the electoral system in Serbia, several small parties from the previous coalition are always needed for the new coalition to form a majority. Therefore, the clean-hands parties, which come into power with the aim of pushing for prosecutions in relation to cases of corruption (in which their predecessors have been implicated), are constrained in doing so by their partners, who were in the previous coalition.

Another concept, labelled mafija [Serb. for mafia], is used in public discourse in Serbia for a specific type of corruption scandal. An important aspect of the cases, named as mafija cases, is that these incidences of corruption are investigated and that implicated parties are prosecuted by state institutions - unlike the cases labelled as afera which have not been investigated or prosecuted, and in which the final court decision has not yet been made. Although mafija cases appear to be very similar to what is known in fully-fledged democracies as corruption scandals, what differentiates them is that they imply a high level of mistrust on the part of the public that the subsequent judgements, reached by courts of law, will be just and impartial. According to two journalists, the accused in mafija cases are usually "people chosen by the state institutions". In other words, the accused are the scapegoats - the individuals who were directly involved in the corrupt practice, such as employees, lower-ranking civil servants or managers - while the high-ranking politicians, who have allegedly masterminded a corrupt scheme are never prosecuted.

All interviewees agreed that the word mafija is used incorrectly and that the term has a high discursive potential to intensify the meaning and raise the visibility of an event. According to an interviewed journalist " $[t]$ he term was coined in 2003 when the Special Department for Fighting Organised Crime was established, and when criminal groups were brought to justice for the first time." However, the state officials and journalists interviewed in my research disagreed about where the term came from or who was the first to introduce it into the public discourse. On the one hand, civil servants argued that the term was coined by journalists in order to attract the attention of the public and increase the popularity of their daily newspapers. Based on the interview with a senior state official, the term mafija is used to replace the legal term 'organised criminal group' and it has few things in common with the meaning of that word in Italy or elsewhere:

"People are fascinated with films about mafia made in Hollywood. The films present the lifestyle of the mafia communities in a romantic way, as people who respect family values, loyalty and commitment to common interests. But what they are, actually... they are organised criminal groups. They are nothing but criminals, and there is nothing romantic about that. Journalists should know the difference and they should not misuse the term only to attract attention." 
Journalists, on the other hand, argue that the term mafija originally came from politicians and state officials, who wanted to promote the work of the newly established court - the Special Department for Fighting Organised Crime. Allegedly, their aim was to present the court to the public as an institution which is ready, willing and well-equipped to investigate complex cases of organised crime and corruption, and to prosecute those involved: "The state itself started naming the cases mafija. At press conferences, the politicians would pay so much attention to those arrests [...]. The state would name everything as mafija, they would make a show of every arrest", said an interviewed journalist. The journalist also added: "Politicians started using this term [mafija] in order to raise their own rating, to suggest that they were solving some big cases."

The mafija-type cases of corruption scandals strengthen the widespread perception amongst the public that investigations and prosecutions have not addressed the core problem. Moreover, they are often interpreted as proof that court decisions are not impartial, which decreases the already low level of trust in state institutions. What is more, the fact that corruption cases have been given final court decisions implies that the reopening of such cases is less likely to happen or even impossible; as such, it is not realistic to expect that the 'true culprits' will be ever punished.

It is important to mention that some corruption scandals are named in the media news as aferas, which suggests that the cases have not been investigated or prosecuted by relevant state institutions. However, the scandal concerning the procurement of the swine flu vaccines can be categorised as mafija, as an investigation of the case was conducted and the actors involved were punished. This indicates that the concepts afera and mafija are not used consistently in public discourse. Some interviewees suggested that strict differentiation between the terms can be misleading as, according to their view, corruption stories are randomly named by capricious journalists. The academic researcher of corruption in Serbia, Professor Petrus van Duyne from the University of Tilburg advised me:

"I think that the name [mafija/afera] is selected at random. In terms of modus operandi I don't see much difference. Nor conceptually or empirically, there is no difference between them. They slightly differ in terms of the network and number of members involved, but not in other things. I wouldn't advise you to take that standard for categorisation."

One more interviewee questioned the reliability of the dual conceptualisation by arguing that, at the moment when an emerging scandal is being named either as afera or mafija, it is difficult to predict with certainty whether the case will be 
prosecuted or not. The dual aspect of the conceptualisation of corruption scandal requires further theoretical and empirical investigation; the findings in this article can, therefore, serve as a starting point for future research.

\section{Conclusions}

The aim of the article is to offer an overview of the literature on political scandals and to present preliminary findings of the research on corruption scandals in Serbia. The article, firstly, follows the conceptualisation, theoretical approaches, operational definitions and typology of corruption scandals over time. The literature review suggests that political scandals are an under-explored topic in research on transitional countries, which are neither full-fledged democracies nor totalitarian regimes. Moreover, the Serbian context is further characterised by the legacy of the armed conflicts in the Balkan region and by the EU accession process. Therefore, the concept of political scandal and its influence on state institutions and political life in general requires a different approach from those identified in the literature. While political scandals can clearly develop in countries not considered to be fully-fledged democracies, the investigation of scandals in transitioning countries requires a somewhat different approach and specific conceptual and methodological tools from both democratic and undemocratic contexts. However, as it is mentioned in the article, the analysis of scandals, published by the Serbian academic community, includes only one academic study, which is concerned with theoretical or methodological issues.

The article, then, offers preliminary findings of the empirical research conducted in Serbia (2012-2013) concerning the concept of corruption scandal as understood in Serbian society. The findings based on 25 interviews suggest that there are two forms of political scandal in public discourse. One involves cases which are under investigation for a prolonged period of time and the final decision of the courts of justice is not expected soon (afera). The other form of scandal (mafija) involves cases which have been investigated by the state authorities, but in which only the lower-ranking public officials are investigated or prosecuted, while politicians and high-ranking officials, who are allegedly involved in the case of corruption, have not been investigated. This dual conceptualisation, however, has not proved to be entirely consistent and reliable, as some prosecuted cases are named afera, and some open-ended stories about political corruption appear in the media as mafija. Therefore, the typology is one of the aspects of the anti-corruption discourse in Serbia that requires further research.

It is important to mention that the field research on this topic was challenged by the reluctance of some members of the elites to participate in the research as the topic of corruption is considered to be a highly-sensitive issue in Serbia. 
Despite these obstacles, further research on political scandals in Serbia would be an invaluable contribution to the understanding of their impact on political developments in the country.

Annex 1:

Academic Literature on Political Scandals

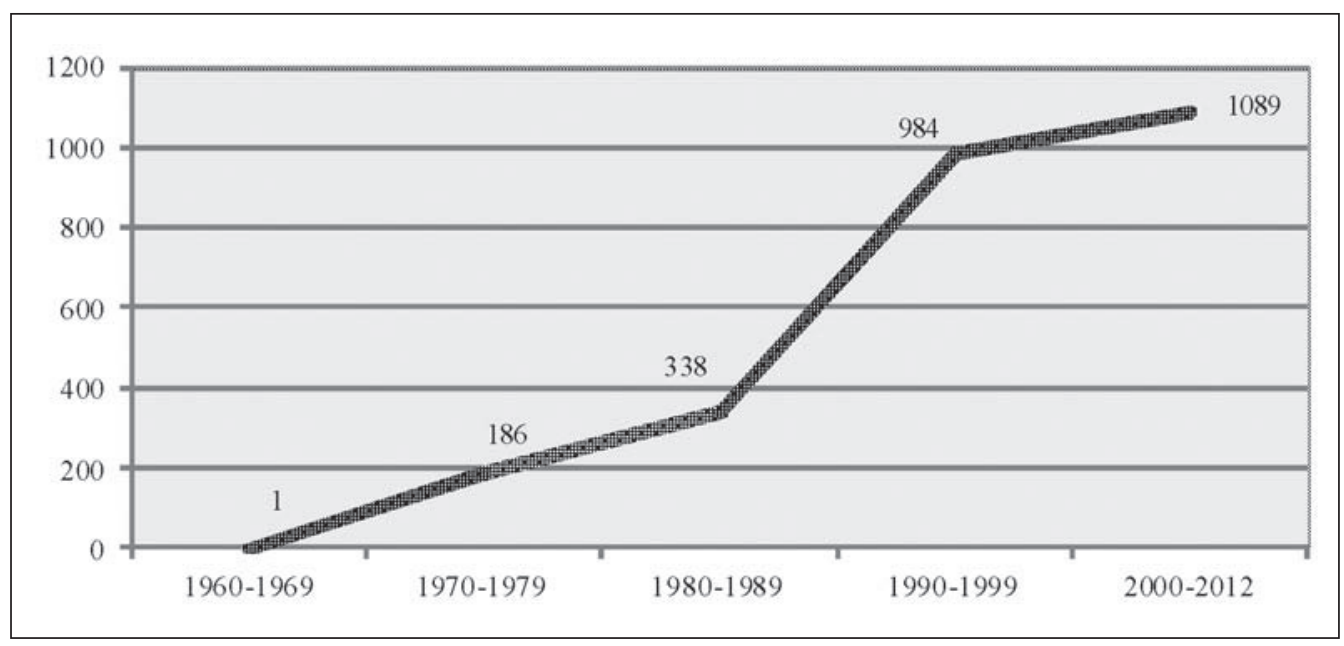

Graph 1 The increase of academic literature on scandals in all disciplines, according to Political Science Abstract database. The analysis includes academic publications with the word scandal in title [on 1 June, 2013]. 


\section{BIBLIOGRAPHY}

Adut, A. (2008). On Scandal: Moral Disturbances in Society, Politics and Art. New York: Cambridge University Press.

Ailon, G. (2012). The Discursive Management of Financial Risk Scandals: The Case of Wall Street Journal Commentaries on LTCM and Enron. Qualitative Sociology 35 (3): 251-270.

Allen, M. and Burrell, N. (2002). The Negativity Effect in Political Advertising: a meta-analysis. In J. P. Dilibard and M. Pfau (eds.), The Persuasion Handbook: Developments in Theory and Practice, Thousand Oaks CA: Sage, pp. 83-96.

Anti-Corruption Council (2011) Report on Pressure and Control Over the Media in Serbia $<\mathrm{http}: / /$ www.antikorupcija-savet.gov.rs> 20.7.2013.

Antonić, S. (2006). Elita, gradjanstvo, slaba država: Srbija posle 2000. Beograd: Službeni glasnik.

Basinger, S. J. and Rottinghaus, B. (2012). Skeletons in White House Closets. Political Science Quarterly 127 (2): 213-239.

Blach-̌̌rsten, M. (2011). Politiske skandaler i danske medier 1980-2010. Tidsskriftet Politik 14 (3): 7-16.

Blaney, J. and Benoit, W. (2001). The Clinton Scandals and the Politics of Image Restoration. Westport CT: Praeger.

Boas, T. C. (2005). Television and Neopopulism in Latin America: Media Effects in Brazil and Peru. Latin American Research Review 40 (2): 27-49.

Bowler, S. and Karp, J. A. (2004). Politicians, scandals, and trust in government. Political Behavior. 26: 271-287.

Brezina, T. and Phipps, H. (2010). False News Reports, Folk Devils, and the Role of Public Officials: notes on the social construction of law and order in the aftermath of Hurricane Katrina. Deviant Behavior 31: 97-134.

Brkić, M. (2013). On the Deeds of Weak Institutions. Belgrade: Center for Applied European Studies.

Bytzek, E. (2007). Ereignisse und ihre Wirkung auf die Popularität von Regierungen: Von der Schleyer-Entführung zur Elbeflut. Baden-Baden: Nomos.

Costas-Perez, E. et al. (2012). Corruption Scandals, Voter Information and Accountability. European Journal of Political Economy 28 (4): 469-484.

Cowley, P. (2002). Revolts \& Rebellions - Parliamentary Voting Under Blair. London: Politico.

Craig, S. C. and Kane, J. G. (2000). Winning and Losing, Sour Grapes, and Negative Ads: The Impact of Election Campaigns on Political Support. Paper presented at Midwest Political Science Association, Chicago, April $10^{\text {th }}-13^{\text {th }}$.

Dafydd, F. (2005). Political and Media Liberalization and Political Corruption in Taiwan. The China Quarterly 184: 875-893.

Damico, A. J. et al. (2000). Patterns of Political Trust and Mistrust: Three Moments in the Lives of Democratic Citizens. Polity 32 (3): 377-400. 
Della Porta, D. (2000). Social capital, beliefs in government and political corruption. In S. J. Pharr and R. D. Putnam (eds.), Disaffected democracies: What's troubling the trilateral countries?, Princeton, NJ: Princeton University Press, pp. 202-230.

Della Porta, D. and Vannucci, A. (1999). Corrupt Exchanges: actors, resources, and mechanisms of political corruption. New York: Aldine de Gruyter.

Della Porta, D. and Vannucci, A. (2012). The Hidden Order of Corruption. An Institutional Approach. Burlington: Ashgate Publishing Ltd.

Djupe, P. and Peterson, D. (2002). The impact of negative campaigning: Evidence from the 1998 senatorial primaries. Political Research Quarterly 55 (4): 845-860.

Doig, A. (1984). Corruption and Misconduct in Contemporary British Politics. London: Penguin Books Ltd.

Dunham, R. G. and Mauss, A. L. (1976). Waves from Watergate: evidence concerning the impact of the Watergate scandal upon political legitimacy and social control. Pacific Sociological Review 19: 469-490.

Ekstrom, M. and Johansson, B. (2008). Talk Scandals, Media, Culture \& Society 30 (1): 61-79.

Entman, R. (2012). Scandal and Silence: Media Responses to Presidential Misconduct. Cambridge: Polity Press.

Esser, F. and Hartung, U. (2004). Nazis, Pollution, and No Sex. Political Scandals as a Reflection of Political Culture in Germany. American Behavioral Scientist 47 (8): 1040-1071.

Finkel, S. E. (1993). Reexamining the 'minimal effects' model in recent presidential campaigns. Journal of Politics 55 (11): 1-21.

Garrard, J. (2006). Scandals: An overview. In J. Garrard and J. L. Newell (eds.), Scandals in Past and Contemporary Politics, Manchester: Manchester University Press, pp. 13-29.

Geer, J. and Lau, R. (2006). Filling in the blanks: A new approach for studying campaign effects. British Journal of Political Science 35 (1): 269-290.

Globetti, S. and Hetherington, M. J. (2000). The negative implications of anti-government campaign rhetoric. Paper presented at Midwest Political Science Association. Chicago, April $10^{\text {th }}$ $13^{\text {th }}$.

Heidenheimer, A. J. (1970). Political Corruption: Readings in Comparative Analysis. New York and London: Holt Rinehart and Winston.

Hondrich, K. O. (2002). Enthüllung und Entrüstung: Eine Phanomenologie des politischen Skandals. Frankfurt am Main: Suhrkamp.

Jackson, R. A. and Carsey, T. M. (2007). U.S. senate campaigns, negative advertising and voter mobilization in the 1998 midterm elections. Electoral Studies 26 (2): 180-195.

Jackson, R. and Sides, J. (2006). Revisiting the influence of campaign tone on turnout in Senate elections. Political Analysis 14 (2): 206-218.

Jimenez, F. and Cainzos, M. (2006). How far and why do corruption scandals cost votes. In J. Garrard and J. L. Newell (eds.), Scandals in past and contemporary politics, Manchester: Manchester University Press, pp. 194-212.

Johnston, M. (1997). Public Officials, Private Interests and Sustainable Democracy: When Politics and Corruption Meet. In K. A. Elliott (ed.), Corruption and Global Economy, Washington: Institute for International Economics, pp. 61-82. 
Kepplinger, H. M. (2001). Handle the Scandal. Some General Aspects of Scandals and some specific Remarks on the Treatment of Helmut Kohl. Studies in Communication Sciences - Studi di scienzedellacomunicazione 1 (2): 117-136.

Kepplinger, H. M. et al. (2012). Framing Scandals: Cognitive and Emotional Media Effects. Journal of Communication. 62 (4): 659-681.

Kepplinger, H. M. and Ehmig, S.C. (2004). Ist die funktionalistische Skandaltheorie haltbar? Ein Beitrag zur Interdependenz von Politik und Medien im Umgang mit Missständen in der Gesellschaft'. In K. Imhof, R. Blum. H. Bonfadelli, O. Jarren (eds.), Mediengesellschaft: Strukturen, Merkmale, Entwicklungsdynamiken, Wiesbaden:Verlag für Sozialwissenschaften, pp. 363-375.

Kerby, M. and Chiari, R. J. (2002). 'Policy Scandal': A Spanish Case. Government and Opposition 37 (3): 409-425.

King, A. (1986). Sex, Money and Power. In R. Hodder-Williams and J. Ceaser (eds.), Politics in Britain and the United States: Comparative Perspectives. Durham N.C.: Duke University Press, pp. 173-222.

Klier P. et. al. (1989). Konvergenz der Skandale? Öffentlichkeit, Publikum und Korruption in der Sowjetunion. In R. Ebbighausen and S. Neckel (eds.), Anatomie des politischen Skandals, Frankfurt am Main: Suhrkamp, pp. 274-306.

Lau, R. et al. (2007). The effects of negative political campaigns: A meta-analytic reassessment. Journal of Politics 69 (4): 1176-1209.

Maier, J. (2002). Politische Skandale - Quelle der Politikverdrossenheit? Zum Einfluss von Fernsehnachrichten über politische Skandale auf Bevölkerungseinstellungen zu Parteien, Politikern und Demokratie in Deutschland. In H. Schatz, P. Rössler, J.U. Nieland (eds.), Politische Akteure in der Mediendemokratie: Politiker in den Fesseln der Medien?, Wiesbaden:Westdeutscher Verlag, pp. 223-240.

Maier, J. (2011). The Impact of Political Scandals on Political Support: An Experimental Test of Two Theories. International Political Science Review 32 (2): 283-302.

McAllister, I. (2000). Keeping them honest: public and elite perception of ethical conduct among Australian legislators. Political Studies 48: 22-37.

Markovits, A. S., Silverstein, M. (1988). Introduction: Power and Process in Liberal Democracies. In A. S. Markovits and M. Silverstein (eds.), The Politics of Scandal: Power and Process in Liberal Democracies, New York: Holmes \& Meier Publishers, pp. 4-5.

Martorano, N. and Uilbig S. G. (2008). The Coingate Effect: The Impact of Scandal on Attitudes Toward State and Federal Political Actors. Paper presented at Annual Meeting of the State Politics and Policy Conference, Philadelphia, PA: May 30-31.

Memoli, V. (2011). Government, Scandals and Political Support in Italy. Interdisciplinary Political Studies 1 (2): 127-136.

Moodie, G. C. (1988). Studying Political Scandal. Corruption and Reform 3 (3): 243-244.

Morris, J. and Clawson, R. (2007). The Media and Congressional Approval. Paper presented at the Annual Meeting of the American Political Science Association.

Neckel, S. (2005). Political Scandals. An Analytical Framework. Comparative Sociology 4 (1/2): 101-111. 
Newell, J. I. (2006). Introduction. In J. Garrard and J. L. Newell (eds.), Scandals in Past and Contemporary Politics. Manchester: Manchester University Press, pp. 1-10.

Noonan, J. T. (1987). Bribes: The Intellectual History of a Moral Idea. Berkeley: University of California Press.

Nyhan, B. (2009). Strategic Outrage: the Politics of Presidential Scandal, $\mathrm{PhD}$ thesis $<$ http://dukespace.lib.duke.edu/dspace/handle/10161/1229> 20.7.2013.

Nyhan, B. and To?as, M. (2008). Passing the Bucks: The Congressional contribution network 19852006. Paper prepared at the American Political Science Association, Boston, MA, August 2831.

Olukoyun, A. (2004). Media Accountability and Democracy in Nigeria, 1999-2003. African Studies Review 47 (3): 69-90.

Pattie, C. and Johnston, R. (2012). The electoral impact of the UK 2009 MPs' expenses scandal. Political Studies 60 (4): 730-750.

Pujas, V. and Rhodes, M. (1998). Party finance and political scandal in Latin Europe $<$ http://www.eui.eu/DepartmentsAndCentres/RobertSchumanCentre/Publications/WorkingPapers/9810.aspx $>$ 2.2.2014.

Renwick, A. et al. (2011). The [Uk] Expenses Scandal And The Politics Of Electoral Reform. Political Quarterly 82 (1): 32-41.

Rose-Ackerman, S. (1999). Corruption and Government: Causes, Consequences, and Reform. Cambridge: Cambridge University Press.

Sabato, L. J. (1991). Feeding Frenzy: How Attack Journalism Transformed American Politics. Free Press: Lanahan Pub Inc.

Sabato, L. J, Stencel, M. and Lichter S. R. (2001). Peep Show: Media and Politics in the Age of Scandal. Lanham: Rowman \& Littlefield.

Sabrow, M. (2004). Politischer Skandal und modern Diktatur. In M. Sabrow (ed.), Skandal und Diktatur: Formen čoffentlicher Empčorung im NS-Staat und in der DDR, Wallstein Verlag, pp. 7-32.

Schmitz, M. (1981). Theorie und Praxis des politischen Skandals. Frankfurt: Campus Verlag.

Schudson, M. (2004). Notes on scandal and the Watergate legacy. American Behavioral Scientist 47: 1231-1238.

Schutze, C. (1967). Die Kunst des Skandals. Wien: Scherz.

Sniderman, P. M. et al. (1975). Stability of support for the political system: the initial impact of Watergate. American Politics Quarterly 3: 437-457.

Svilanović, T. (2012). Privatizacija C Marketa. Unpublished paper.

Thompson, J. B. (2000). Political Scandal: Power and Visibility in the Media Age. Cambridge: Polity Press.

Thompson, J. B. (1995). The Media and Modernity: A Social Theory of the Media. Stanford: Stanford University Press.

Tiffen, R. (1999). Scandals: media, politics and corruption in contemporary Australia. New South Wales: University of New South Wales Press.

Tileaga, C. (2012). The Right Measure of Guilt: Moral Reasoning, Transgression and Social Construction of Moral Meanings. Discourse and Communication 6 (2): 203-222. 
Toepfl, F. (2011). Managing Public Outrage: power, scandal and new media in contemporary Russia. New Media and Society 13 (8): 1301-1319.

Tumber, H. (2004). Scandal and Media in the United Kingdom: From Major to Blair. American Behavioral Scientist 47 (8): 1122-1137.

Tumber, H. and Waisbord, S. R. (2004). Introduction: Political Scandals and Media across Democracies, Volume 1. American Behavioral Scientist 47: 1031-1039.

Van Dalen, A. and Skovsgaard, M. (2011). Erenpolitiskskandale en politiskskandale? Danske medierede politiske skandaler i et komparativt perspektiv. Tidsskriftet Politik 14 (3): 17-26.

Vannucci, A. (2009). The Controversial Legacy of 'Mani Pulite': A Critical Analysis of Italian Corruption and Anti-Corruption Policies. Bulletin of Italian Politics 1: 233-264.

Vivyan, N. et al. (2012). Representative Misconduct, Voter Perceptions and Accountability: Evidence from the 2009 [UK] House of Commons Expenses Scandal. Electoral Studies 31 (4): 750-763.

Williams, B., Delli Carpini, M. (2000). Unchained reaction: The collapse of media gatekeeping and the Clinton-Lewinsky scandal. Journalism: Theory, Practice, and Criticism 1: 61-85.

\section{INTERVIEW LIST}

Anonymous source, Civil Servant, Ministry of Justice, 27 October 2012.

Anonymous source, Civil Servant, Ministry of Justice, 12 August 2012.

Anonymous source, NGO sector, 20 October 2012.

Anonymous source, Journalist, 20 October 2012.

Antonić, Slobodan, Professor, Faculty of Sociology, University of Belgrade, 10 August 2012.

Babović, Ana, Member of the NGO Serbia in Motion; former Head of the Department at the Office of the Deputy Prime Minister for European Integration and Development (2007-2012), 12 June 2011.

Barlovac, Bojana, Journalist at the Balkan Investigative Reporting Network (BIRN), 3 August 2012.

Begović, Boris, Professor, Faculty of Law, University of Belgrade; Founder and director of the NGO Centre for Liberal Democratic Studies, 20 August 2012.

Ćemalović, Uroš, Adviser for Law Harmonisation, Department for European Integration, Parliament, 2 June 2012.

Čvorović, Miodrag, Producer of the investigative journalist serial on political corruption Insajder at TV B92, 3 August 2012.

Goati, Vladimir, President of the NGO Transparency International, 12 August 2012.

Janjić, Dušan, President of the NGO Forum for ethnic relations; political analyst, 22 August 2012. Jevtović, Mirjana, journalist at TV B92, 25 August 2012.

Jovanović, Dragana, president of the NGO Doctors against Corruption; former Municipal Secretary of Health, Belgrade (13 October 2008 - 22 October 2009); Professor, Faculty of Medicine, University of Belgrade, 20 August 2012.

Karadjinović, Draško, Vice President of the NGO Doctors against Corruption; doctor of medicine, 20 August 2012. 
Milivojević, Andjela, Journalist at the Centre for Investigative Journalism in Serbia (CINS), 8 August 2012.

Minić, Zlatko, Journalist and Member of the Anti-Corruption Agency's Board, 5 August 2012.

Ninić, Ivan, Member of the NGO Whistle, 20 August 2012.

Pašić, Jasmina, Journalist at TV B92, 3 August 2012.

Pešić, Vesna, Independent MP; Ambassador of FR Yugoslavia and the State Union of Serbia and Montenegro to Mexico (2001-2005), 21 October 2012.

Radomirović, Vladimir, Editor in chief at the NGO Whistle, 3 August, 2012.

Stojiljković, Zoran, Professor, Faculty of Political Science, University of Belgrade; President of the Anti-Corruption Agency's Board since 2011, 23 August, 2012.

Šabić, Rodoljub, Commissioner for Information of Public Importance and Personal Data Protection, 10 August 2012.

Udovički, Kori, Assistant Secretary-General of United Nations, Director of the Regional Bureau of UNDP for Europe and CIS and Assistant Administrator of UNDP (1 February 2007 - 22 February 2012); Governor of the National Bank of Serbia (22 July 2003 - 1 March 2004); Minister of Mining and Energy (19 June 2002 - 22 July 2003), 26 October 2012.

Van Duyne, Petrus, Professor, Law School, Tilburg University; researcher in the area of money laundry and corruption in Serbia, 21 October 2012. 
Марија Зурнић

Summary

Независни истраживач

\section{ИСТРАЖИВАЮЕ КОРУПЦИЈСКИХ АФЕРА У СРБИЈИ: НОВИ ПРИСТУПИ И ПРОБЛЕМИ}

Све већи број коруйцијских афера на йолийичкој сцени у Србији и недовољно научних радова на ову йему, били су йодсиичцај за израду овоі истираживања. У йрвом делу, рад износи йостиојеће йеорије, ӣојмове и дефиниције коруйиијских афера у науч-

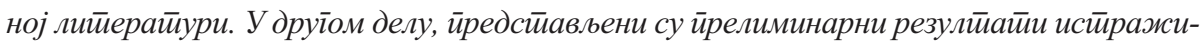
вана заснованої на 25 иниеервјуа, обавељених йоком 2012. и 2013. іодине, са државним службеницима, универзитиетиским йрофесорима и члановима невладиної сектиора у Србији. Резулитайи истираживања указују да йосӣоје две врсйе коруйцијских скандала у јавним дебайама о коруйцији - афера и мабија. Ауйор исиииче да разновр-

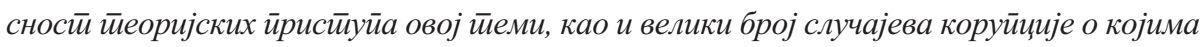
средстива информисања извешйавају, йредстиављају изазов и йодсиичиај за будућа научна истираживања.

Кључне речи: коруйција, ӣолит̄ички скандали, Србија 